Article

\title{
Influences of Multiscale Land Cover Characteristics and Specific Conductivity on Fish Assemblages in the Nolichucky River Watershed, Tennessee
}

\author{
Hayley S. Gotwald and J. Brian Alford* \\ The University of Tennessee, Institute of Agriculture, Department of Forestry, Wildlife, and Fisheries, 274 \\ Ellington Plant Sciences Bldg., Knoxville, TN 37996, USA; hgotwald@vols.utk.edu \\ * Correspondence: jalfor12@utk.edu; Tel.: +01-865-974-8752
}

\begin{abstract}
We evaluated the potential of using fish species and functional traits as indicators of land use impacts to fish assemblages. We used environmental data collected at multiple spatial scales (local, reach, and upstream catchment) for 19 tributary and main stem sites in the Nolichucky River watershed in Tennessee. Canonical correspondence analyses showed that temperature, elevation, specific conductivity, sediment yield, impervious surfaces, and row crop cover at the catchment scale were strongly associated with fish assemblage structure, as well as forest cover from all three spatial scales. Blocked indicator species analysis, with stream size as the block, showed that significantly strong indicators of the least-impacted riparian land use condition ( $\geq 60 \%$ forest cover) were Saffron Shiner (Notropis rubricroceus), Rainbow Trout (Oncorhyncus mykiss), Longnose Dace (Rhynichthys cataractae), Creek Chub (Semotilus atromaculatus), and Mottled Sculpin (Cottus bairdi). Traits indicative of the least-impacted sites were the herbivorous trophic guild, mean female ageat-maturity, longevity, rock-gravel spawners, montane geology and pelagic swimmers. Specific conductivity was strongly related to multiple catchment-scale land use variables, and was a strong local-scale influence on fish assemblage structure. Our results show promise for using a relatively common but endemic southern Appalachian fish species, the Saffron Shiner, as an indicator for land-use related impacts to these streams.
\end{abstract}

Keywords: spatial scale; CCA; indicator species analysis; land use; SWAT; bioassessment

\section{Introduction}

Land cover change is one of the major drivers of aquatic species extinction worldwide [1-3]. As forested watersheds are converted to agricultural and urban uses, hydrological changes ensue, and sediment, chemical, and nutrient runoff degrade stream fish habitat [4-6]. The greatest levels of endemism and richness of freshwater aquatic biota in the temperate biome occurs in the Southeastern U.S., and land use is a primary threat to extinction of rare, endemic species in the region [2,7]. Habitat degradation imparted by land use activities may homogenize an aquatic community by allowing more pollution-tolerant species or cosmopolitan species (i.e., broad home range) to dominate the assemblage, pushing more sensitive and endemic species out and increasing extinction rates [8-9].

In the Nolichucky River watershed of east Tennessee (USA) (Figure 1), there are five fish and seven mussel species listed as endangered or threatened by the State or the U.S. Fish and Wildlife Service, making it one of the most critically important "hot spots" for North American aquatic biodiversity [10,7]. However, since 1999 there has been an $83 \%$ increase in the conversion of pasture/hay and forest acreage into row crop agriculture, mostly in corn and tomato production [11]. Nutrient runoff and subsequent increases in primary production as well as chemical runoff from impervious surfaces can degrade stream ecosystems [2,4,9]. In addition, sedimentation from unbuffered crop fields and cattle pastures can smother fish eggs and gills and saturate crevices needed by fishes for shelter, spawning, or foraging [3,5]. Currently, the Chucky Madtom (Noturus 
crypticus) is a federally endangered catfish that is known from just one creek in the Nolichucky River watershed (Little Chucky Creek). However, the species has not been detected since 2004, due in part to uncontrolled agricultural and pastoral runoff that has magnified suspended sediments and filled in rock crevices it requires for spawning, nesting, and shelter. Additionally, the Sharphead Darter (Etheostoma acuticeps) is restricted to shallow riffle habitats in the main stem Nolichucky River and is listed as vulnerable by the IUCN. Sedimentation of riffles could endanger the species and allow more generalist or cosmopolitan species to take hold $[2,8]$.

The purpose of this project is to assess the influence of land use at multiple spatial scales in the Nolichucky River watershed on fish assemblage structure. We had three primary questions for this project: (i) is there a relationship between land use intensity measured at different spatial scales and fish species and functional trait composition, (ii) can indicator fish species or functional traits be identified to potentially monitor impacts from land use, and (iii) are there local-scale water quality characteristics that are directly attributable to variation in land use and fish assemblage change?

\section{Materials and Methods}

\subsection{Sample site selection}

Nineteen sample sites (Figure 1) were selected semi-qualitatively based on observation of land use activities in the riparian zone. Observations were made by traveling throughout the watershed to choose sites that were subjectively categorized into three classes: (a) least-impacted (minimal land use within $30 \mathrm{~m}$ of the stream bank for $2 \mathrm{~km}$ upstream of the site and clear water), (b) moderatelyimpacted (some amount of land use within $30 \mathrm{~m}$ of the stream bank but still a forested riparian buffer and moderately clear water), and (c) most-impacted by land use (land use occurred up to the stream bank, water very turbid from suspended sediments, greater than $50 \%$ land use within $2 \mathrm{~km}$ upstream of the site. Site classifications were confirmed by calculating the interquartile range of percentage forest cover in ArcGIS v. 10.1 at the reach scale (1500-m length) with a 125-m buffer around the reach. Least-impacted reaches contained $\geq 60 \%$ forest in the sample reach riparian zone, moderatelyimpacted reaches had $37-59 \%$ forest cover, and reaches most-impacted by land use contained $<37 \%$ forest cover. One tributary and one main stem site were sampled in 2014 and 2015 to account for any temporal changes in fish species composition, but none were observed. 


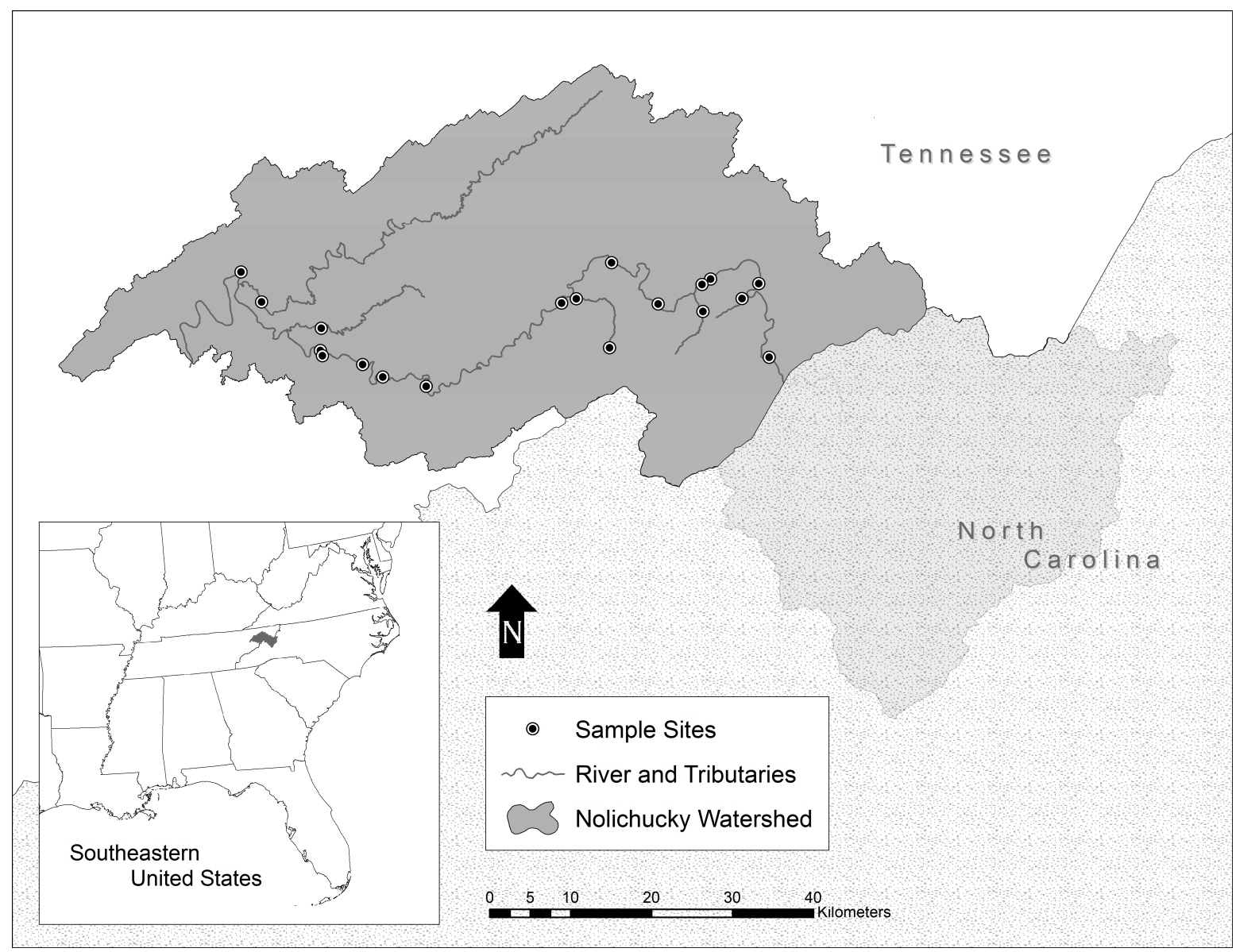

Figure 1. Study area showing the Nolichucky River watershed in Tennessee and the sample sites where fish and water quality data were collected.

Variation in stream fish assemblage structure due to natural geomorphic factors were accounted for by measuring elevation and by categorizing sites as tributary (low order creeks that drained into the Nolichucky main stem) and main stem Nolichucky sites. This was done because fish assemblages are different with respect to changes in water temperature (e.g., higher elevation, shaded canopy sites), discharge (e.g., lower in tributary sites), and substrate size (e.g., larger substrates in tributaries) [12].

\subsection{Instream environmental and land cover data acquisition}

A YSI 6600 Sonde (Yellow Springs, Inc., Yellow Springs, OH) was used to collect water quality data prior to fish sampling. Environmental characteristics tested included water temperature $\left({ }^{\circ} \mathrm{C}\right)$, $\mathrm{pH}$, dissolved oxygen concentration $(\mathrm{mg} / \mathrm{L})$ and percent saturation, specific conductivity $(\mu \mathrm{S} / \mathrm{cm})$, and total dissolved solids (ppm). After the fish sample, a rapid habitat assessment was conducted following U.S. EPA's Environmental Monitoring and Assessment Protocol for high gradient streams [13]. Each site was scored qualitatively for habitat quality with possible scores ranging 0-200.

Landsat 8 Operational Land Imager (OLI) satellite data at path 18, row 35 with minimal cloud cover were acquired for 2014 during the visible growing season. Satellite images were preprocessed using the software ENVI version 4.8 (Exelis Visual Information Solutions 2010). Radiometric correction was performed to produce reflectance values, and atmospheric correction was completed with a dark body subtraction (Level II Normalized Difference Vegetation Index (NDVI) [14] scenes that were derived from Landsat surface reflectance images were acquired from the USGS's Earth Resources Observation and Science Center (EROS) to aid the classification and differentiation between row crops and open fields. Aerial photographs from 2014 that were coincident with the 
satellite data were acquired to provide training areas for supervised classifications and ground truth sample sites for accuracy assessments of the resulting thematic maps.

To help separate row crops from open fields (i.e., hay, pasture, and fallow fields), a mask was created for the NDVI time series using the 2011 U.S. Geological Survey's (USGS) National Land Cover Dataset's (NLCD) impervious surface layers, the USGS National Hydrography Dataset's (NHD) vector data of open water, and the forested land cover identified in the supervised classification of the Landsat 8 image. After the land cover map was produced, the NHD flow lines were used to create $100-\mathrm{m}$ and $125-\mathrm{m}$ buffers around streams for measuring land cover percentage at multiple spatial scales.

\subsection{Land cover classification}

A maximum likelihood supervised classification approach in combination with a normalized difference vegetation index calibrated density slice (NDVI) [14-15] was used to produce a land use/land cover (LULC) map with 4 classes: forest, impervious, row crop, and open field. After the thematic map was created for 2014, several measurements were taken at three spatial scales: local, reach, and catchment (Figure 2). The catchment scale was all land cover in the sample site's upstream catchment. Catchments for each site were delineated using the Arc Hydro toolset version 2.0 [16]. Catchment-scale riparian buffers of 100-m were also created around the entire NHD flow line network upstream of each study site. In addition to percentages of land use, patch density of row crops was measured to account for fragmentation of the landscape. To be considered a patch, the area was relatively homogeneous and differed from the surrounding land use [17]. Patch density was expressed as number of row crop patches $/ \mathrm{km}^{2}$. 


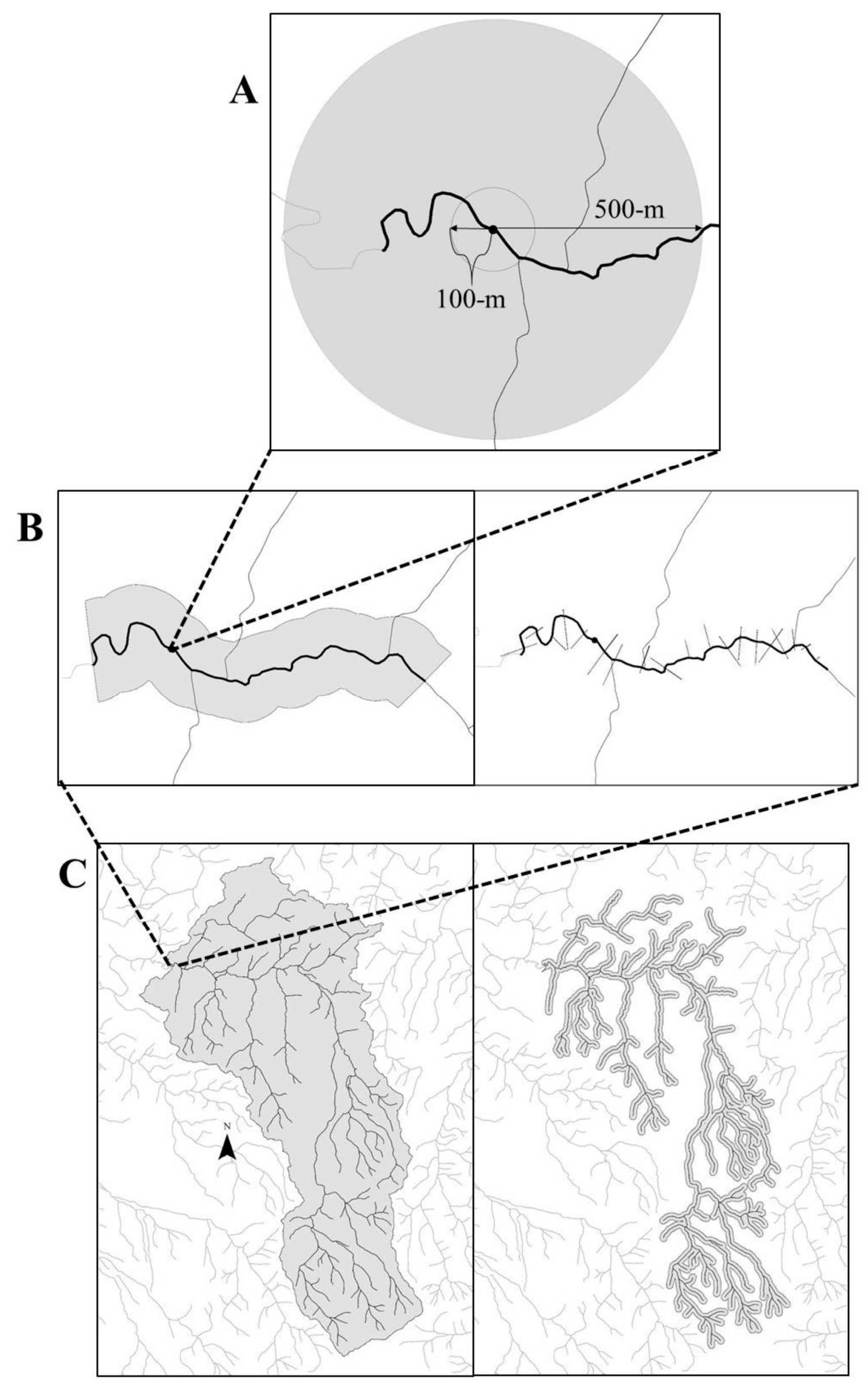


Figure 2. Measurements for the scale analysis in the Nolichucky River watershed for the 2014 map. Part $\mathrm{A}$ is at the local scale which are a 500-m and 100-m point buffers around the sample location. Visual representation of the spatial scales of measured land cover. Part C shows the area used to calculate percent land use of the entire catchment (left) and a 100-m buffer of the entire upstream riparian network (right). Part B shows the reach scale that includes a buffer that is 1000-m upstream and 500-m downstream of the sample location (left: where the dashed lines meet). A buffer of 125-m was created around the reach and the width of the riparian vegetation was measured perpendicular to the stream at 50-m increments from the upstream to downstream end of the reach (right). Illustration is taken from [11] with permission of the author.

At the reach spatial scale, land use was characterized following the method of [18] by examining a 1500-m long reach encompassing the fish sample site, whereby a 1000-m segment of the reach was upstream of the sample site and a 500-m segment was downstream of the sample site. A riparian buffer of 125-m was created for the entire 1500-m reach. Using U.S. Department of Agriculture's National Agriculture Imagery Program (NAIP) photos for 2014, land use was digitized and summed as percentages for each buffer length. In addition to the buffers, woody vegetation distance was measured perpendicular to the reach. At the reach scale, frequency of intact forested riparian habitat at 30-m buffer width [19], was calculated from the vegetative width measurements. For the local spatial scale, a 100- and 500-m circular point buffer was created to measure land use percentage from the thematic map (see Figure 2). In addition to land use, all instream water quality data were considered to be reflective of the local spatial scale.

\subsection{Catchment-scale SWAT model simulations}

To assess the amount of non-point source pollutant runoff in each catchment, the ArcSWAT 2012 model was used to simulate the amount of sediment, nitrogen and phosphorus yield for each sample site for 2014. Mandatory spatial input files needed for the model included the input digital elevation model (DEM), land use map, and soil layer. Using the DEM a catchment was created for each sample site. The catchments were divided into hydrologic response units (HRUs) by (LULC), slope levels, and soil percentage. The HRUs are areas in the model that are calculated to have the same manner in which they conduct water through the system to the sample site. Land use and slope were reclassified in the SWAT model. Land use was classified as agriculture row crops, mixed forest, water, residential medium/low density, and pasture. The slope was classified into five classes based on natural breaks in the percent rise value in the raster.

The SWAT output file was a measurement of sediment yield, organic nitrogen, and organic phosphorus for each catchment. The model was run on a monthly time step during 2014. Sediment yield (SYLD) was reported as metric ton/ha and is the sediment from the catchment that is transported to the sample site during the time step. Organic nitrogen yield (ORGN) was reported as the ORGN transported out of the catchment and into the sample site during the time step. Organic phosphorus yield (ORGP) was reported as g/ha and is the amount of ORGP transported out of the catchment and into the sample site during the time step the amount of ORGP transported [20]. The measurements for all months were totaled for SYLD, ORGN, and ORGP yields transported to the sample sites during 2014. More detailed descriptions of all methods regarding land use data acquisition and SWAT modeling can be found in Gotwald (2016).

\subsection{Fish sampling}

During summer 2014-2016, we used Tennessee Valley Authority (TVA) standard sampling protocols. Fish were sampled in riffle-run habitats by simultaneously kicking the stream bottom and back-pack electrofishing ( $60 \mathrm{~Hz}, \mathrm{AC}$ ) into a 3 × $6 \mathrm{~m}$ seine net (untreated nylon, 6-mm mesh). Sample areas for electrofishing sets were standardized to $28 \mathrm{~m}^{2}$, and sampling continued in a habitat type until it was "depleted" of species. That is, sampling occurred until three consecutive runs yielded no 
new species for riffle and run habitats. All fish were identified after each electrofishing sample run, counted, and released alive immediately into the stream. Fish sampling methods were approved under IACUC protocol \#2257-0414 by the University of Tennessee-Knoxville.

\subsection{Statistical analysis}

Canonical correspondence analysis (CCA) was conducted with a $4^{\text {th }}$-root transformed main matrix of fish abundances (fish $/ \mathrm{m}^{2}$ ) for each electrofishing sample. A secondary matrix of independent predictor variables was used to identify multi-scale environmental factors that structured fish assemblages in riffle-run habitats. These included a categorical variable for reach-scale riparian land use (least, moderate, most impact), local-scale water quality variables, as well as local-, reach, and catchment-scale land cover variable. Finally, natural geomorphic variables included elevation at mean sea level and stream size (i.e., tributary or main stem). Integer data were $\log _{\mathrm{e}}$ transformed, and proportion data were arcsine-square root transformed to improve multivariate normality and normalize the ranges of environmental data. A Monte Carlo randomization procedure was run 499 times to determine if the axes and correlations between the species abundance matrix and environmental matrix were statistically significant $(\mathrm{P}<0.05)$. The CCA was run in PC-Ord v. 6.15. A cutoff of $R^{2}=0.34$ was used on the resulting joint-plots to minimize the number of environmental vectors (i.e., arrows) that were associated significantly with the axes

Blocked Indicator species analysis (B-ISA) was used to determine the fish species and functional traits that were the most abundant and frequent for the least-, moderate-, and most-impacted riparian land use classifications [21]. The blocking variable was stream size. The B-ISA score is calculated using the percent composition and frequency of occurrence data for each species at each site. Scores range $0-100$, where B-ISA $>25$ was considered to be strong for a particular classification type. Statistical significance $(\alpha=0.05)$ of B-ISA scores were calculated using 999 runs of a Monte Carlo randomization. These analyses were run in PC-Ord v. 6.15.

The CCA and B-ISA were also run on a matrix of fish functional trait abundances. Two complementary analyses were conducted because variation in functional traits can provide meaningful insights into changes in fish assemblage structure [21-23]. Traits were obtained for each species from the online Virginia Tech Fish Traits database (http://www.fishtraits.info/search/attr/). No information exists for Highland Shiner (Notropis micropteryx), so Rosyface Shiner (Notropis rubellus) information was used, because Highland Shiner was formerly classified as Rosyface Shiner. The functional trait analysis was done to see if there were particular guilds of fish that were being impacted by land use, rather than particular taxonomic species, because fishes with similar adaptations to an environmental factor may occupy a habitat more frequently than fishes that are taxonomically similar (e.g., same genus) but functional disparate. Traits belonged to three general categories, including life history strategy, trophic group, and habitat preference.

Finally, a simple linear regression analysis was conducted a aposteriori on the link between land use at various spatial scales and the local-scale factor of specific conductivity. This was done because specific conductivity (and the highly collinear variable total dissolved solids) tended to vary with respect to land cover differences as opposed to natural gradients such as elevation, stream size, or catchment area. This local-scale water quality factor has a direct impact on the daily physiological demands of fish as opposed to land cover characteristics. Thus, it is important to demonstrate a threeway link between land use, water quality, and fish assemblage structure.

\section{Results}

A total of 9,157 fish representing 51 species were captured from 385 electrofishing samples in riffle-run habitats. Land cover was comprised mostly of forest, regardless of spatial scale, followed by open fields (Table 1). Organic nitrogen yield and sediment yield from the SWAT model outputs and open field land cover varied the most among catchments. However, at the reach scale with 125- 
$\mathrm{m}$ buffer, row crops had considerably greater percent land cover compared to row crop coverage from other spatial scales (Table 1). With regard to water quality, specific conductivity and total dissolved solids showed the greatest variability in concentrations across sites.

Table 1. A descriptive summary of environmental data collected during 2014-2016 at multiple spatial scales at 18 sites in the Nolichucky River watershed, Tennessee.

\begin{tabular}{|c|c|c|c|c|}
\hline Spatial Scale & Characteristic & $\underline{\text { Mean }}$ & $\underline{\operatorname{Max}}$ & $\underline{\text { Min }}$ \\
\hline \multirow[t]{9}{*}{ Catchment } & Area $\left(\mathrm{km}^{2}\right)$ & 1798.9 & 4229.0 & 14.2 \\
\hline & Organic nitrogen yield $(\mathrm{kg} / \mathrm{ha})$ & 5.3 & 12.9 & 0.6 \\
\hline & Sediment yield (metric tons/ha) & 9.0 & 51.4 & 0.2 \\
\hline & Organic phosphorus yield (kg/ha) & 0.9 & 2.1 & 0.1 \\
\hline & $\%$ Row crop & 1.1 & 3.8 & 0.0 \\
\hline & $\%$ Open field & 22.7 & 66.0 & 4.7 \\
\hline & $\%$ Forest & 72.4 & 95.3 & 24.0 \\
\hline & $\%$ Impervious & 3.8 & 11.5 & 0.0 \\
\hline & Row crop patches $/ \mathrm{km}^{2}$ & 0.5 & 3.0 & 0.0 \\
\hline \multirow[t]{4}{*}{$\begin{array}{l}\text { Catchment: 100-m } \\
\text { buffer }\end{array}$} & $\%$ Row crop & 0.8 & 3.4 & 0.0 \\
\hline & $\%$ Open field & 23.7 & 67.4 & 2.4 \\
\hline & $\%$ Forest & 70.7 & 97.6 & 22.4 \\
\hline & \% Impervious & 4.7 & 10.4 & 0.0 \\
\hline \multirow{4}{*}{$\begin{array}{l}\text { Reach: } 125-\mathrm{m} \\
\text { buffer }\end{array}$} & $\%$ Row crop & 15.8 & 64.7 & 0.0 \\
\hline & $\%$ Open field & 29.1 & 62.0 & 4.0 \\
\hline & $\%$ Forest & 51.5 & 95.1 & 22.7 \\
\hline & \% Impervious & 3.6 & 7.7 & 0.9 \\
\hline Reach: 30-m buffer & $\%$ Forest & 56.5 & 98.3 & 3.4 \\
\hline \multirow[t]{4}{*}{ Local: 500-m buffer } & $\%$ Row crop & 4.6 & 17.2 & 0.0 \\
\hline & $\%$ Open field & 40.3 & 70.9 & 0.2 \\
\hline & $\%$ Forest & 47.3 & 98.0 & 7.6 \\
\hline & \% Impervious & 5.1 & 11.5 & 0.6 \\
\hline \multirow[t]{4}{*}{ Local: $100-\mathrm{m}$ buffer } & \% Row crop & 0.8 & 8.6 & 0.0 \\
\hline & \% Open field & 19.9 & 74.3 & 0.0 \\
\hline & $\%$ Forest & 62.8 & 100.0 & 0.0 \\
\hline & $\%$ Impervious & 5.0 & 45.9 & 0.0 \\
\hline \multirow[t]{5}{*}{ Local } & Rapid habitat assessment & 146.0 & 180.0 & 93.0 \\
\hline & $\mathrm{pH}$ & 7.8 & 9.2 & 6.6 \\
\hline & Total dissolved solids (ppm) & 157.1 & 416.0 & 8.4 \\
\hline & Temperature $\left({ }^{\circ} \mathrm{C}\right)$ & 21.5 & 27.0 & 12.1 \\
\hline & Dissolved oxygen conc. (mg/L) & 9.3 & 13.6 & 6.6 \\
\hline
\end{tabular}




$\begin{array}{llll}\text { Specific conductivity }(\mu \mathrm{S} / \mathrm{cm}) & 183.0 & 570.0 & 12.0 \\ \text { Elevation }(\mathrm{m}) \text { above MSL } & 462.6 & 638.0 & 316.0\end{array}$

\subsection{CCA of fish species and functional trait abundances against multi-scale environmental matrix}

With regard to taxonomic species (Figure 3), the CCA suggested that fish assemblages were structured primarily along a gradient of water temperature and land use at multiple spatial scales (species-environment correlations: axis 1, r = 0.97, $\mathrm{P}=0.002,499$ Monte Carlo runs; axis 2, $\mathrm{r}=0.93$ ). Water temperature, elevation, specific conductivity, and land cover of all types at local, reach, and catchment scales were the dominant environmental variables that were associated with axes 1 and 2 . In particular, sediment yield, impervious surfaces, and row crop cover at the catchment scale were strongly associated with variation in fish assemblage structure, as well as forest cover from all three spatial scales. These land cover variables were significantly correlated with elevation, temperature, and specific conductivity at the local scale. Although there were some similarities in fish assemblage structure with respect to riparian land use classification (i.e., least, moderate-, and most-impacted), there were clear differences in fish assemblages with respect to increasing land use and natural changes in elevation and water temperature. Fish assemblages from most-impacted sites were associated with higher specific conductivity, warmer water temperatures, greater impervious surfaces and open fields in their catchments, but lesser forest cover. In contrast, fish assemblages from least-impacted sites were characterize as having lower specific conductivity, cooler water temperatures, impervious surfaces, and open fields, with greater amounts of forest cover in catchments.

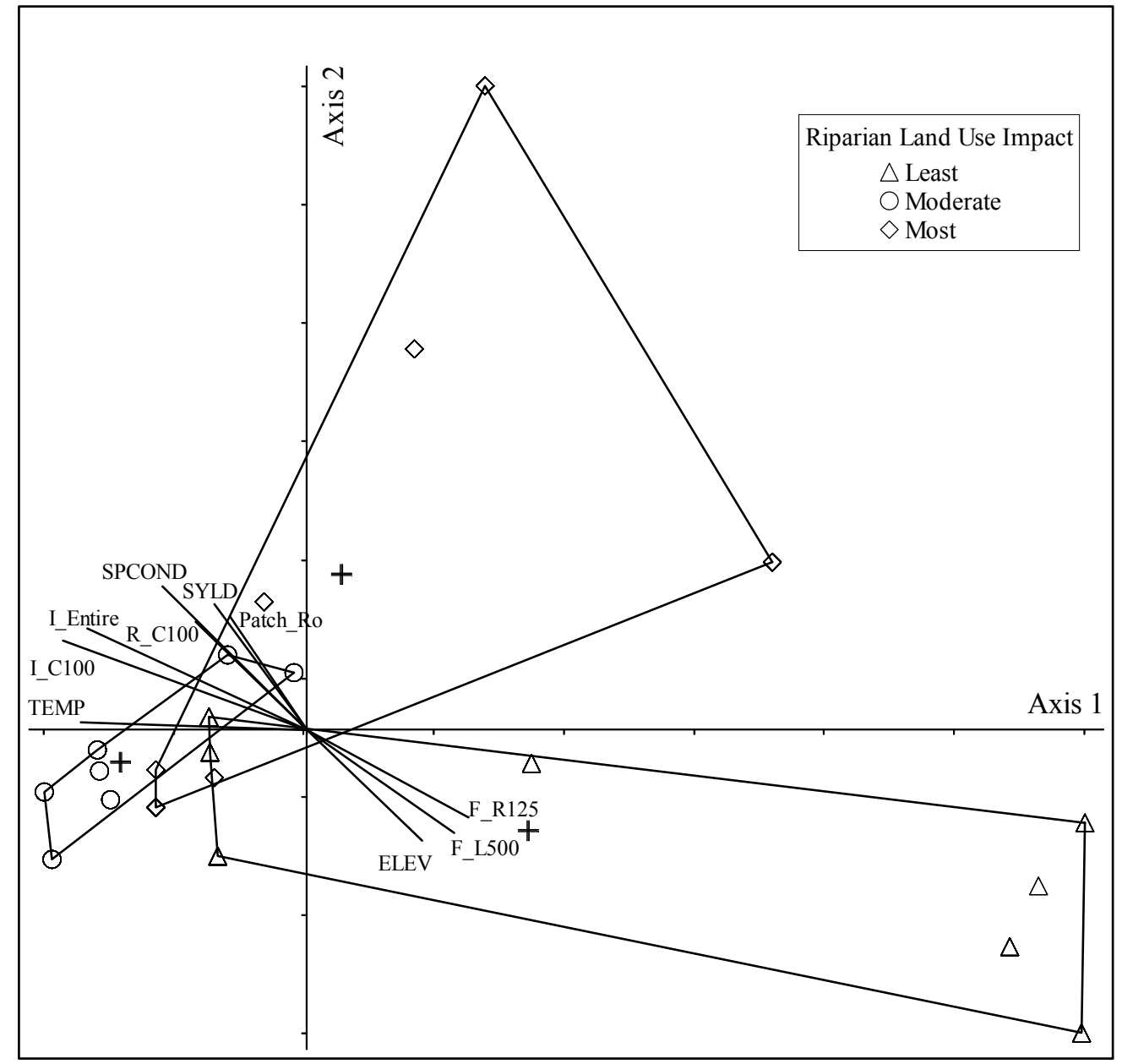

Figure 3. Joint plot of a canonical correspondence analysis (CCA) of fish species abundance matrix and a secondary matrix of environmental data collected at multiple spatial scales (local, reach, and 
upstream catchment). Environmental variables (arrows) with strong correlations ( $R^{2} \geq 0.34$ ) with the axes are shown. Convex hulls surround the sample scores for each of three reach-scale riparian land use classifications (see Table 2). SPCOND = specific conductivity, SYLD = sediment yield from SWAT model, Patch_Ro $=$ number of catchment-scale row crop patches $/ \mathrm{km}^{2}$, I_Entire $=\%$ impervious surfaces in entire catchment, R_C100 $=\%$ row crops in entire catchment within a 100-m riparian buffer, I_C100 $=\%$ impervious surfaces in entire catchment within a 100-m riparian buffer, TEMP = water temperature, ELEV = elevation at mean sea level, F_L500 $=\%$ local-scale forest cover within 500-m buffer, F_R125 = \% reach-scale forest cover within a 125-m riparian buffer.

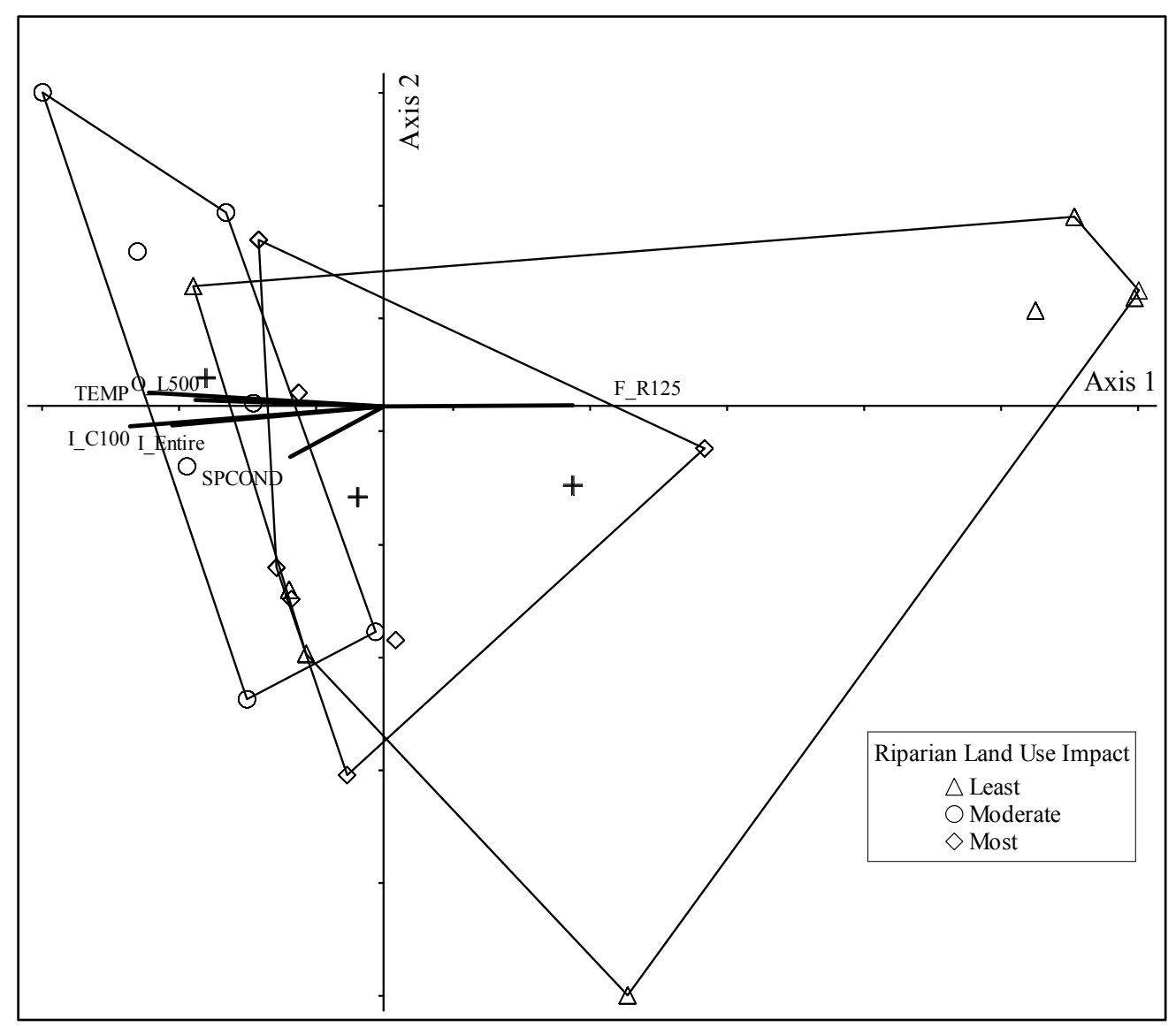

Figure 4. Joint plot of a canonical correspondence analysis (CCA) of fish functional trait abundance matrix and a secondary matrix of environmental data collected at multiple spatial scales (local, reach, and upstream catchment). Environmental variables (arrows) with strong correlations $\left(R^{2} \geq 0.34\right)$ with the axes are shown. Convex hulls surround the sample scores for each of three reach-scale riparian land use classifications (see Table 2). See Figure 3 for abbreviation definitions.

Inspection of the functional trait CCA joint plot (Figure 4) suggests that the same trends exist with regard to land use and changes in water temperature (species-environment correlations: axis 1 , $\mathrm{r}=0.95, \mathrm{P}=0.002,499$ Monte Carlo runs; axis 2, $\mathrm{r}=0.75$ ). More specifically, impervious surface coverage at the catchment scale (entire and 100-m buffer), open field cover local scale (500-m buffer) as well as forest cover at the reach scales (125-m buffer) were most important. Similar to the taxonomic CCA, specific conductivity was strongly associated with changes in functional trait structure of fish assemblages. Likewise, there was some overlap in functional trait structure among riparian land use classifications (primarily most-impacted sites with least-impacted sites), but clear differences among some sites were observed, especially between least-impacted and moderatelyimpacted sites. 


\subsection{Blocked indicator species analyses}

The B-ISA confirmed the CCA results, showing that particular species were strong indicators of the three riparian land use classifications (Table 2). Srong indicator species $(\mathrm{IV}>25 ; \mathrm{P}<0.05)$ of the least-impacted riparian land use condition were Saffron Shiner (Notropis rubricroceus), Rainbow Trout (Oncorhyncus mykiss), Longnose Dace (Rhynichthys cataractae), Creek Chub (Semotilus atromaculatus), and Mottled Sculpin (Cottus bairdi). Fish species indicative of moderately-impacted sites were Gilt Darter (Percina evides), Highland Shiner, Redline Darter (Etheostoma rufilineatum), and Wounded Darter (Etheostoma vulneratum). Sites that were most-impacted by riparian land use were indicated by 17 species (see Table 2).

Table 2. Blocked indicator species analysis for fish species in the Nolichucky River watershed sampled in riffle-run habitats during summer 2014-2016. Stream size was the blocking factor (main stem or tributary) and riparian land use impact from row-crops, open fields (including cattle pastures), and impervious surfaces was the main factor (least, moderate, most impacted). Asterisks are species that were considered strongly significant $(\mathrm{IV}>25.0$; P-value $\leq 0.05)$ indicators for a particular land use category. FC = forest cover.

\begin{tabular}{|c|c|c|c|c|}
\hline Riparian Impact & $\underline{\text { Scientific Name }}$ & $\underline{\text { Common Name }}$ & $\underline{\text { IV }}$ & $\begin{array}{l}P \text { - } \\
\text { value }\end{array}$ \\
\hline Least $(\geq 60 \%$ FC) & Notropis rubricroceus & Saffron Shiner* & 92.4 & 0.002 \\
\hline Least & Oncorhyncus mykiss & Rainbow Trout* & 68.8 & 0.002 \\
\hline Least & Rhinichthys cataractae & Longnose Dace ${ }^{*}$ & 61.2 & 0.002 \\
\hline Least & Semotilus atromaculatus & Creek Chub* & 59.0 & 0.004 \\
\hline Least & Etheostoma chlorobranchium & Greenfin Darter & 51.0 & 0.092 \\
\hline Least & Cottus bairdi & Mottled Sculpin* & 50.3 & 0.028 \\
\hline Least & Luxilus coccogenis & Warpaint Shiner & 50.2 & 0.202 \\
\hline Least & Percina aurantiaca & Tangerine Darter & 46.0 & 0.112 \\
\hline Least & Pylodicitis olivaris & Flathead Catfish & 45.3 & 0.265 \\
\hline Least & Micropterus dolomieu & Smallmouth Bass & 44.3 & 0.082 \\
\hline Least & Campostoma anomalum & Central Stoneroller & 39.2 & 0.283 \\
\hline Moderate (37-59\% FC) & Percina evides & Gilt Darter* & 67.3 & 0.002 \\
\hline Moderate & Notropis micropteryx & Highland Shiner* & 60.3 & 0.002 \\
\hline
\end{tabular}




\begin{tabular}{|c|c|c|c|c|}
\hline Moderate & Etheostoma rufilineatum & Redline Darter* & 59.9 & 0.002 \\
\hline Moderate & Percina caprodes & Common Logperch & 54.5 & 0.224 \\
\hline Moderate & Notropis leuciodes & Tennessee Shiner & 54.1 & 0.092 \\
\hline Moderate & Etheostoma vulneratum & Wounded Darter* & 52.9 & 0.006 \\
\hline Moderate & Etheostoma camurum & Bluebreast Darter & 51.3 & 0.202 \\
\hline Moderate & Noturus eleutherus & Mountain Madtom & 47.6 & 0.098 \\
\hline Moderate & Ichthyomyzon bdellium & Ohio Lamprey & 44.8 & 0.505 \\
\hline Moderate & Notropis photogenis & Silver Shiner & 43.9 & 0.499 \\
\hline Moderate & Pimephales vigilax & Bullhead Minnow & 43.3 & 0.705 \\
\hline Moderate & Hypentelium nigricans & Northern Hogsucker & 42.1 & 0.214 \\
\hline Moderate & Notropis volucellus & Mimic Shiner & 38.5 & 1.000 \\
\hline Moderate & Notemigonus chrysoleucas & Golden Shiner & 37.1 & 0.583 \\
\hline Moderate & Etheostoma acuticeps & Sharphead Darter & 35.2 & 0.914 \\
\hline Most ( $\leq 36 \%$ FC) & Percina squamata & Olive Darter* & 60.7 & 0.002 \\
\hline Most & Moxostoma erythrurum & Golden Redhorse* & 59.8 & 0.002 \\
\hline Most & Luxilus chrycocephalus & Striped Shiner* & 59.6 & 0.002 \\
\hline Most & Notropis straminea & Sand Shiner* & 59.1 & 0.002 \\
\hline Most & Moxostoma breviceps & Smallmouth Redhorse & 59.0 & 0.004 \\
\hline Most & Erimystax insignis & Blotched Chub* & 57.9 & 0.002 \\
\hline Most & Etheostoma kennicotti & Stripetail Darter* & 57.4 & 0.008 \\
\hline Most & Phenacobius uranops & Stargazing Minnow ${ }^{*}$ & 56.6 & 0.032 \\
\hline Most & Cyprinella galactura & Whitetail Shiner* & 56.0 & 0.002 \\
\hline
\end{tabular}




\begin{tabular}{|c|c|c|c|c|}
\hline Most & Moxostoma carinatum & River Redhorse* & 50.5 & 0.042 \\
\hline Most & Notropis telescopus & Telescope Shiner* & 49.8 & 0.048 \\
\hline Most & Etheostoma simoterum & Snubnose Darter* & 48.1 & 0.004 \\
\hline Most & Lepomis auritus & Redbreast Sunfish & 47.7 & 0.998 \\
\hline Most & Eheostoma zonale & Banded Darter* & 47.4 & 0.050 \\
\hline Most & Moxostoma duquesnei & Black Redhorse* & 47.2 & 0.016 \\
\hline Most & Hybopsis amblops & Bigeye Chub & 47.1 & 0.361 \\
\hline Most & Lepomis cyanellus & Green Sunfish & 46.7 & 0.980 \\
\hline Most & Catastomus commersoni & White Sucker & 46.7 & 0.992 \\
\hline Most & Etheostoma jessiae & Blueside Darter & 46.7 & 1.000 \\
\hline Most & Cyprinella spiloptera & Spotfin Shiner & 46.1 & 0.241 \\
\hline Most & Cottus carolinae & Banded Sculpin* & 45.9 & 0.008 \\
\hline Most & Ambloplites rupestris & Rock Bass & 45.8 & 0.345 \\
\hline Most & Etheostoma blennioides & Greenside Darter* & 44.6 & 0.022 \\
\hline Most & Nocomis micropogon & River Chub & 43.6 & 0.253 \\
\hline Most & Rhinichthys atratulus & Blacknose Dace $^{*}$ & 42.5 & 0.042 \\
\hline
\end{tabular}

Select functional traits were also indicative of the three riparian land use classifications. Traits indicative of the least-impacted sites were herbivorous trophic guild, mean female age-at-maturity, longer life span, and adaptions to spawning on rock-gravel substrates, montane geology and swimming at the water surface (Table 3). Fish that spawn in aquatic plants attached to rocks, such as Riverweed (Podostemum ceratophyllum) and Water Willow (Justicia americana), were indicative of the moderately-impacted condition. Similarly, life history strategies were indicative of the mostimpacted condition and included longer spawning season, being a batch spawner, peak spawning period in July and August, and laying eggs in small substrates like gravel and sand.

Table 3. Blocked indicator species analysis for fish functional traits in the Nolichucky River watershed sampled in riffle-run habitats during summer 2014-2016. Stream size was the blocking factor (main stem or tributary) and riparian land use impact from row-crops, open fields (including 
cattle pastures), and impervious surfaces was the main factor (least, moderate, most impacted). Asterisks are species that were considered strongly significant (IV > 25.0; P-value $\leq 0.05)$ indicators for a particular land use category. FC = forest cover.

\section{$\underline{\text { Riparian Impact }} \underline{\text { Trait Category }} \quad \underline{\text { Trait Description }} \quad \underline{\text { IV }} \underline{\text { P-value }}$}

\begin{tabular}{|c|c|c|c|c|}
\hline Least $(\geq 60 \% \mathrm{FC})$ & Trophic Group & Herbivore (macrophytes)* & 41.3 & 0.002 \\
\hline Least & Life History & Mean female age at maturity* & 37.9 & 0.002 \\
\hline Least & Habitat Use & Montane geology* & 37.7 & 0.018 \\
\hline Least & Habitat Use & Water surface* & 37.4 & 0.002 \\
\hline Least & Life History & Longevity* & 37.2 & 0.012 \\
\hline Least & Life History & Maximum total length & 36.7 & 0.299 \\
\hline Least & Habitat Use & Gravel & 35.2 & 0.980 \\
\hline Least & Trophic Group & Predator (fish, crayfish, frogs, etc.) & 34.9 & 0.309 \\
\hline Least & Habitat Use & Small river & 34.8 & 1.000 \\
\hline Least & Habitat Use & Benthic & 34.7 & 1.000 \\
\hline Least & Trophic Group & Invertebrates and larval fish & 34.7 & 1.000 \\
\hline Least & Habitat Use & Creek & 34.4 & 1.000 \\
\hline Least & Habitat Use & Fast current & 33.8 & 0.974 \\
\hline Least & Trophic Group & Algae and phyytoplankton & 33.7 & 0.192 \\
\hline Least & Habitat Use & Aquatic vegetation (e.g., Podostemum) & 31.9 & 0.080 \\
\hline Least & Trophic Group & Eggs & 29.3 & 0.768 \\
\hline Least & Life History & $\begin{array}{l}\text { Non-guarding open lithophils (rock- } \\
\text { gravel)* }\end{array}$ & 26.6 & 0.002 \\
\hline Least & Life History & Nest guarding speleophil (cavity-roof) & 24.7 & 0.074 \\
\hline Least & Habitat Use & Pools & 21.6 & 0.002 \\
\hline
\end{tabular}




\begin{tabular}{|c|c|c|c|c|}
\hline Least & Habitat Use & Pelagic zone & 14.7 & 0.002 \\
\hline Moderate (37-59\% FC) & Life History & Non-guarding open phytolithophils* & 37.6 & 0.002 \\
\hline Moderate & Habitat Use & Sand & 31.1 & 0.948 \\
\hline Moderate & Trophic Group & Detritus & 30.7 & 0.483 \\
\hline Moderate & Life History & Brood hiding lithophil (rock-gravel) & 27.4 & 0.551 \\
\hline Moderate & Life History & $\begin{array}{l}\text { Brood hider speleophil (wood, cans, } \\
\text { etc.) }\end{array}$ & 16.0 & 0.074 \\
\hline Moderate & Life History & Non-guarding open pelagophil & 16.0 & 0.004 \\
\hline Moderate & Life History & Non-guarding lithophil (gravel-sand) & 13.3 & 0.056 \\
\hline Moderate & Life History & $\begin{array}{l}\text { Nest guarding speleophil (cavity } \\
\text { generalist) }\end{array}$ & 2.1 & 0.174 \\
\hline Moderate & Habitat Use & Large woody debris & 1.8 & 0.647 \\
\hline Moderate & Life History & Non-guarding open phytophil & 0.9 & 0.463 \\
\hline Most $(\leq 36 \% \mathrm{FC})$ & Life History & Long spawning season* & 38.7 & 0.002 \\
\hline Most & Habitat Use & Maximum July temperature tolerance & 36.7 & 0.265 \\
\hline Most & Life History & Batch spawner* & 36.5 & 0.002 \\
\hline Most & Habitat Use & Large river & 36.1 & 0.349 \\
\hline Most & Habitat Use & Moderate current & 36.1 & 0.726 \\
\hline Most & Life History & Mean fecundity & 35.9 & 0.992 \\
\hline Most & Life History & Peak spawn in July* & 34.9 & 0.002 \\
\hline Most & Habitat Use & Boulder & 34.3 & 0.998 \\
\hline Most & Life History & Peak spawn in August* & 34.1 & 0.002 \\
\hline Most & Habitat Use & Cobble & 34.1 & 1.000 \\
\hline
\end{tabular}


Most

Most

Most

Most

Most

Most

Most

Most
Habitat Use

Bedrock

$32.7 \quad 0.293$

Habitat Use

Clay-silt*

$28.5 \quad 0.010$

Habitat Use

Slow current

$28.4 \quad 0.445$

Life History

Non-guarding lithophils (gravel-sand)*

$25.4 \quad 0.050$

Life History Nest guarding lithophils

$15.7 \quad 0.168$

Life History

Non-guarding openpPsammophils

$8.9 \quad 0.002$

Life History

Nest guarding polyphils

$4.5 \quad 0.078$

\subsection{Linear regressions between land use variables and specific conductivity}

Simple linear regressions revealed that catchment-scale variation in nitrogen runoff and land cover percentages explained significant amounts of variation $\left(\mathrm{R}^{2}>0.51-0.79 ; \mathrm{P}<0.05\right)$ in specific conductivity at sample sites (Figure 5). More specifically, increasing amounts of organic nitrogen yield, catchment-scale row crop cover and row crop patches, as well as catchment-scale impervious surface cover were associated with increasing concentrations of specific conductivity. In contrast, increasing catchment-scale percentages of forest cover were strongly associated with lower specific conductivity levels. As a check against natural changes in specific conductivity due to geomorphic variability, catchment area $\left(\mathrm{R}^{2}=0.05 ; \mathrm{P}=0.31\right)$ was not associated with specific conductivity. Meanwhile, elevation had a significant but weak $\left(\mathrm{R}^{2}=0.35 ; \mathrm{P}=0.01\right)$ negative relationship to specific conductivity. Thus, sites lower in the watershed's valley, where land use is logically most intense, tended to have greater specific conductivity, but this was not related to stream size. 
Preprints (www.preprints.org) | NOT PEER-REVIEWED | Posted: 17 February 2017

doi:10.20944/preprints201702.0067.v1

17 of 22

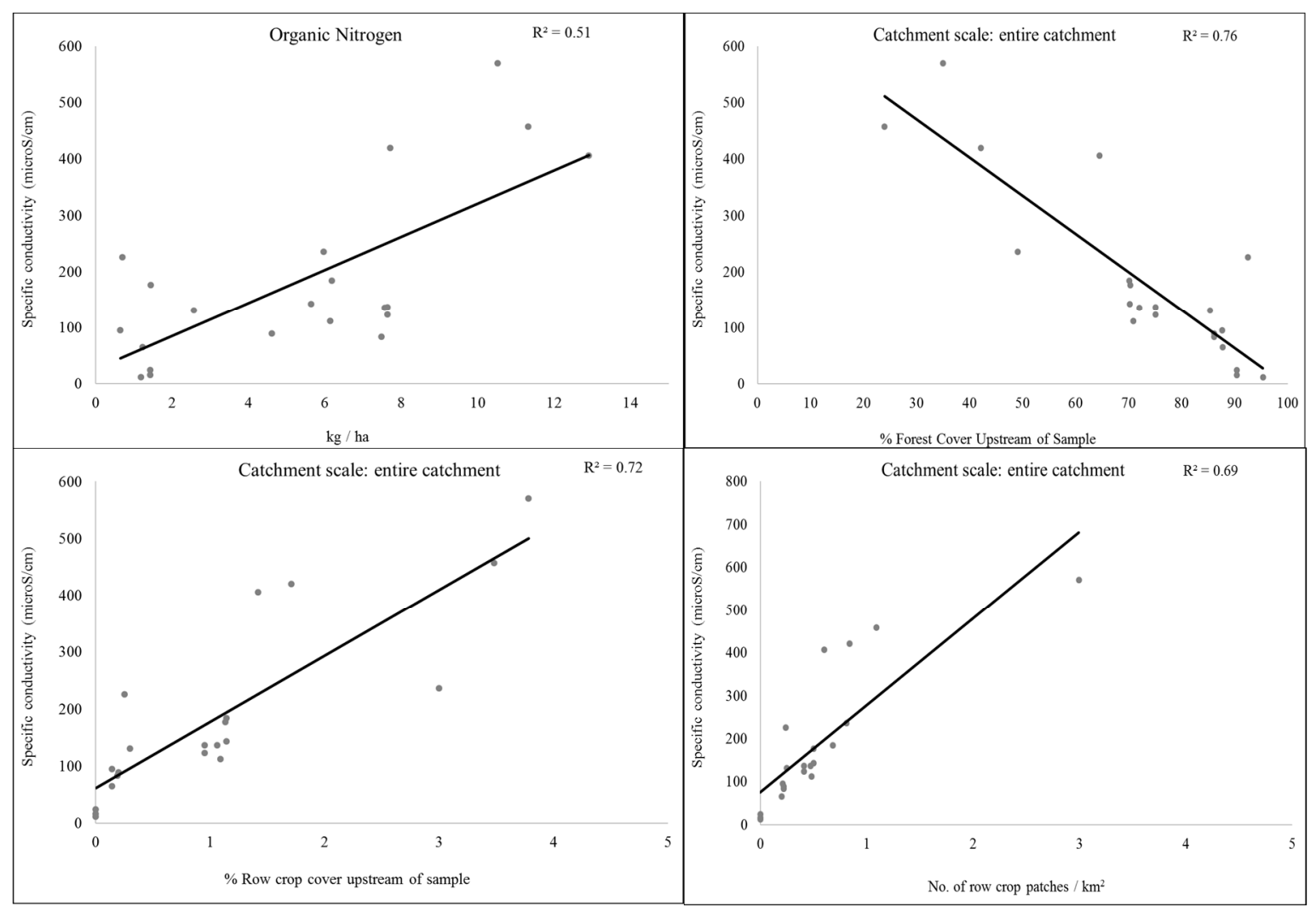



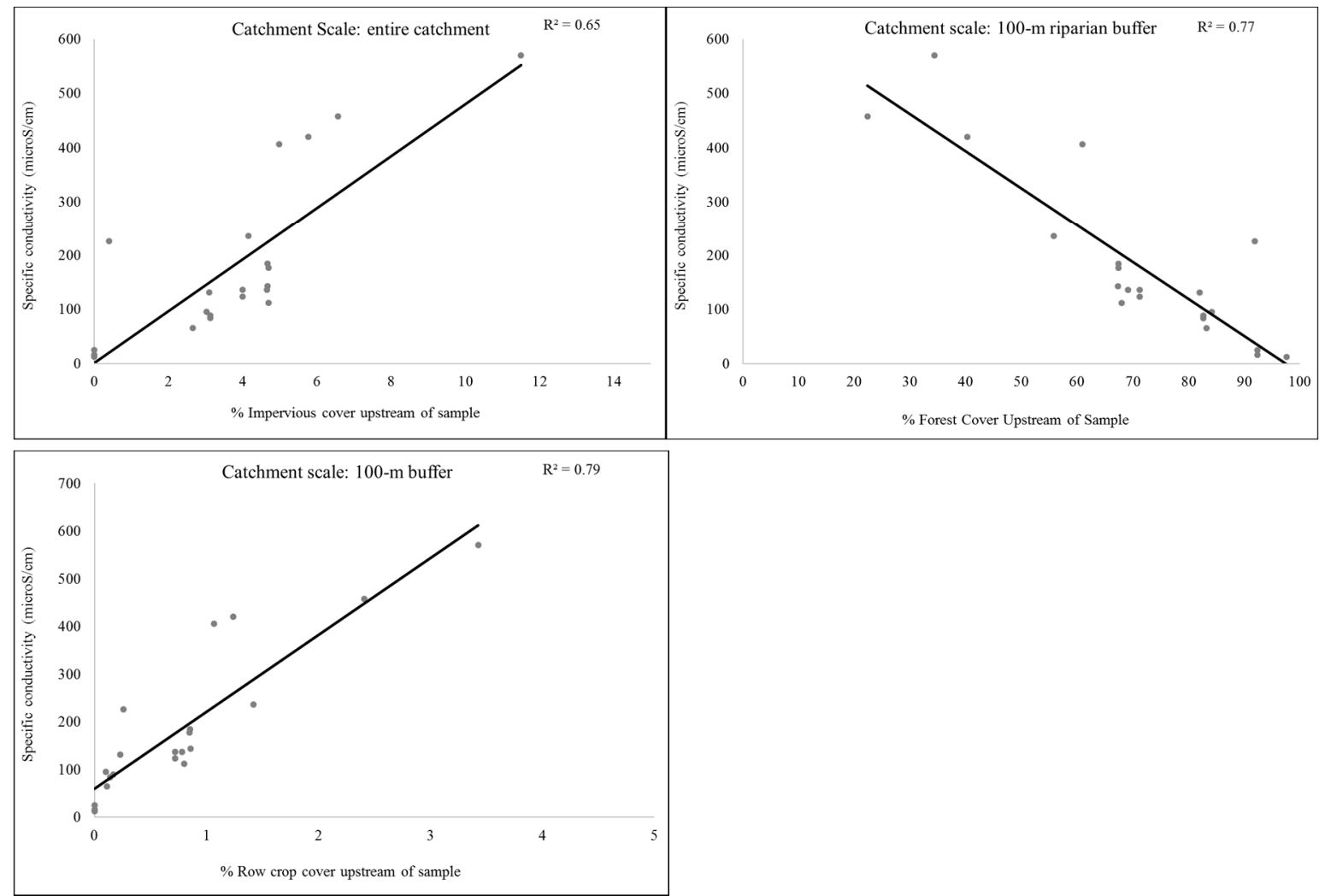

Figure 5. Simple linear regressions of land cover variables against specific conductivity measured in the Nolichucky River watershed, Tennessee during summer 2014-2016. Only statistically significant and strong regressions are shown $\left(\mathrm{R}^{2}>0.50 ; \mathrm{P}<0.05\right)$.

\section{Discussion}

In the Nolichucky River watershed, fish assemblages in riffle-run habitats are different with respect to local-, reach- and catchment-scale land cover. However, differences in fish assemblage structure caused by land use is confounded by natural variation in elevation and water temperature. Although, increases in water temperature may also be caused by reductions in riparian forest cover, especially at tributary sites. Nonetheless, fish taxa and functional traits indicative of sites leastimpacted by land use were reflective of the "equilibrium" end of the triangular classification scheme of fish life histories [25]. Other studies have found that environmental factors measured at multiple scales are important to structuring fish assemblages, and that equilibrium species tend to occur in stable habitats that are not subject to extreme anthropogenic disturbances such as flashy stream flows, sedimentation, and chemical pollution [6,18, 26-28]. Moreover, land use occurring in riparian zones, regardless of spatial scale, has a direct negative impact on aquatic ecosystems by increasing sedimentation, and chemical loads, water temperatures which directly impacts fish physiology and reproductive success, and by decoupling energetic pathways important to fish food webs (24, 29-32).

In our study, the Saffron Shiner was the strongest indicator species for the least-impacted reachscale riparian land use condition. Thus, it occurred most frequently and was most numerically abundant when riparian forest cover within a 125 -m buffer was $\geq 60 \%$. Life history studies have shown that Saffron Shiners occur in high and low elevation streams within its range and lay eggs in small numbers over River Chub (Nocomis micropogon) nests that are defended by males [33]. Saffron shiners in the Nolichucky River watershed may by limited by suspended sediments that persist even at base flows in tributary reaches with $>40 \%$ land use in riparian zones. Several tributary streams, including Little Chucky Creek where the endangered Chucky Madtom occurs, have persistent suspended sediment loads with very little sediment on the stream bottom. This may inhibit sensitive species by smothering gill filaments, filling in crevices where they may spawn, or it may impede their ability to capture drifting invertebrate prey via reduced visual acuity. Negative effects of suspended 
sediments have been shown to reduce the visual acuity of the drift-feeding Rosyside Dace (Clinostomus funduloides) in Georgia [34-35]. In an experimental lab setting, suspended sediment reduced growth rate and gill condition in Whitetail Shiners (Cyprinella galactura), a common species in the southern U.S. Appalachian region, as well as Spotfin Chub (Erimonax monachus), a threatened species in the region that showed more intense negative effects than that of its more cosmopolitan relative [36]. Thus, suspended sediments due to deforestation, even at base flow condition [37], can negatively alter fish assemblages and lead to species displacement or extirpation [8].

In terms of functional trait relationships, fishes that prefer pool habitats with aquatic vegetation and rocky substrates were also important indicators of the least-impacted riparian condition, reflecting a lack of excessive sedimentation at least-impacted sites. In contrast, "opportunistic" life history patterns were more indicative of sites heavily impacted by land use. These included traits such as batch spawning, long reproductive seasons, broadcast pelagic spawners, and fish that prefer fine sediments. In moderate- and most-impacted sites, as long as river flows remain natural with connected riffle-run-pool habitat patches, then relatively rare species that are endemic to the southeastern U.S. Appalachian region may persist. For example, the Olive Darter (Percina squamata) was the strongest indicator species for sites most-impacted by riparian land use, but it is considered near threatened by the IUCN. Likewise, the Sharphead Darter, whose global distribution is restricted to the main stem of the Nolichucky River, was the most numerically dominant species in our samples, but inhabited riffle-run habitats regardless of riparian land use condition and was not a significant indicator of any land use category in our study. Interestingly, Creek Chub occurrence probability from hierarchical Bayesian multispecies models in North Carolina streams was positively associated with catchment forest cover and negatively associated with agricultural land cover [38], yet the Creek Chub is considered by state and federal management agencies to be a pollution-tolerant species. It has been shown that physiological stress responses of Creek Chub become elevated in sites where riparian buffers were deforested [39]. Thus, species tolerance assignments either need to be reevaluated, or perhaps functional trait approaches should be considered when assigning tolerance levels for fish-based bioassessments [40].

In our study, specific conductivity was positively correlated with increasing percentages of land cover and estimated nitrogen yield from the SWAT model. In reference wadeable streams in the Central Appalachian Mountain region (e.g., least-disturbed by anthropogenic activities), specific conductivity is typically $<150 \mu \mathrm{S} / \mathrm{cm}$, but sites impacted by coal mine leaching can exceed $1,000 \mu \mathrm{S} / \mathrm{cm}$ [41-42]. Moreover, non-point runoff from impervious surfaces and point-source effluents from storm water and wastewater treatment plants are also known to increase specific conductivity [43]. In the upper French Broad River drainage in North Carolina, specific conductivity and associated land cover change were strong indicators of fish assemblage change from minnow-dominated (Cyprinidae) to sunfish-dominated (Centrarchidae) species [44]. We found that specific conductivity was the second strongest correlate to fish assemblage structural differences after water temperature. Saffron Shiners, Creek Chub, Rainbow Trout, Mottled Sculpin, and Longnose Dace were negatively influenced by specific conductivity, which was directly related to increases in row crops, open fields, and most importantly impervious surfaces. Regression-modeled occurrences and abundances of Kentucky Arrow Darter (Etheostoma spilotum) and Blackside Dace (Chrosomus cumberlandensis) from Kentucky and Tennessee (USA) declined significantly when specific conductivity surpassed an estimated $261 \mu \mathrm{S} / \mathrm{cm}$ and $343 \mu \mathrm{S} / \mathrm{cm}$, respectively, and that agricultural and urban land uses were directly related to increases in specific conductivity [45]. Because of its relative ease of measurement and association with fish assemblage integrity, specific conductivity should be a strong candidate for use by water quality monitoring programs in the absence of fish sampling as a first-order assessment of anthropogenically-induced ecosystem change in watersheds draining the southern U.S. Appalachian mountain region.

In summary, Saffron Shiners seem to be the most likely indicator species of land use impacts in tributary sites in the Nolichucky River watershed, especially since they were never collected in high impact tributary sites and only $2 \%$ of individuals were sampled from moderately-impacted sites. Suspended sediments may play a larger role in filtering out crevice-spawning species such as Saffron 
Shiner [34]. We could not measure sedimentation in this study, but all tributary sites that were considered moderately- or most-impacted by land use had clear, visual evidence of suspended sediment loads. The impact of suspended sediment to biotic integrity, along with specific conductivity to assess non-point chemical runoff, should be investigated further. The indicator species approach involves tracking the occurrence and/or abundance of common species as a surrogate for either (i) degradation of biotic integrity or (ii) restoration potential for imperiled, endemic species that may be difficult to encounter (e.g., Chucky Madtom). Our results show promise for using a relatively common but endemic southern Appalachian fish species as an indicator for land-use related impacts to water quality and physical habitat in these streams.

Acknowledgments: The authors thank the University of Tennessee Institute of Agriculture and the Tennessee Water Resources Research Center for funding this research. Joyce Coombs, Justin Wolbert, Daniel Walker, Todd Amacker, Parker Hurst, Keith Garner, and Charlie Saylor were instrumental in helping with field data collection. We thank Dr. Robert Washington-Allen and Dr. Andrea Ludwig (UTK) for their valuable advice on multiscale GIS processing and data analyses.

Author Contributions: JBA conceived the design of the study, collected and analyzed the fish and water quality data. HSG collected fish, water quality, and GIS data. HSG and JBA wrote the paper.

Conflicts of Interest: The authors declare no conflict of interest. The founding sponsors had no role in the design of the study in the collection, analyses, or interpretation of data in the writing of the manuscript, and in the decision to publish the results.

\section{References}

1. Allan, J.D. Landscapes and riverscapes: the influence of land use on stream ecosystems. Annu. Rev. Ecol. Evol. Syst. 2004, 35, 257-284, DOI: 10.1146/annurev.ecolsys.35.120202.110122.

2. Jelks, H.L.; Walsh, S.J;; Burkhead, N.M.; Contreras-Balderas, S.; Diaz-Pardo, E.; Hendrickson, D.A.; Lyons, J.; Mandrak, N.E.; McCormick, F.; Nelson, J.S.; Plantania, S.P.; Porter, B.A.; Renaud, C.B.; Schmitter-Soto, J.J.; Taylor, E.B.; Warren, Jr., M.L. Conservation status of imperiled North American freshwater and diadromous fishes. Fisheries. 2008, 33, 372-407, DOI: 10.1577/1548-8446-33.8.372.

3. Utz, R.M.; Hilderbrand, R.H.; Raesly, R.L. Regional differences in patterns of fish species loss with changing land use. Biol. Conserv. 2010, 143, 688-699, DOI: 10.1016/j.biocon.2009.12.006.

4. Allan, J.D.; Erickson, D.; Fay, J. The influence of catchment land use on stream integrity across multiple spatial scales. 1997. Freshwater Biol., 37, 149-161, DOI: 10.1046/j.1365-2427.1997.d01-546.x.

5. Wang, L.; Seelbach, P.; Lyons, J. Effects of levels of human disturbance on the influence of catchment, riparian, and reach-scale factors on fish assemblages. In Landscape Influences on Stream Habitats and Biological Assemblages. Hughes, R.M., Wang, L., Seelbach, P.W., Eds.; American Fisheries Society: Bethesda, Maryland, USA, 2006; Symposium 48, pp. 199-219.

6. Marzin, A.; Verdonschot, P.F.M.; Pont, D. The relative influence of catchment, riparian corridor, and reachscale anthropogenic pressures on fish and macroinvertebrate assemblages in French rivers. Hydrobiologia. 2013, 704, 375-388, DOI:10.1007/s10750-012-1254-2.

7. Smith, G.R.; Badgley, C.; Eiting, T.P.; Larson, P.S. Species diversity gradients in relation to geological history of North American freshwater fishes. Evol. Ecol. Res. 2010, 12, 693-726.

8. Scott, M.C. Winners and losers among stream fishes in relation to land use legacies and urban development in the southeastern US. Biol. Conserv. 2006, 127, 301-309, DOI: 10.1016/j.biocon.2005.07.020.

9. Hitt, N.P.; Roberts, J.H. Hierarchical spatial structure of stream fish colonization and extinction. Oikos 2012, 121, 127-137, DOI: 10.1111/j.1600-0706.2011.19482.x.

10. Tennessee Department of Environment and Conservation (TDEC). Tennessee River and Stream Assessment Project. Tennessee Department of Conservation, Nashville, Tennessee, USA, 2008.

11. Gotwald, H.S. Impacts of land use disturbance on fish and aquatic macroinvertebrate assemblages in the Nolichucky River watershed. Masters Thesis, University of Tennessee, Knoxville, Tennessee, USA, August 2016.

12. Vannote, R.L.; Minshall, G.W.; Cummins, K.W.; Sedell, J.R.; Cushing, C.E. The river continuum concept. Can. J. Fish. Aquat. Sci. 1980, 37, 130-137. 
13. Barbour, M.T; Gerritsen, J.; Snyder, B.D.; Stribling, J.B. Rapid bioassessment protocols for use in streams and wadeable rivers. USEPA, Washington, D.C., 1999.

14. Rouse, Jr., J.W.; Haas, R.H.; Deering, D.W.; Schell, J.A.; Harlan, J.C. Monitoring the vernal advancement and retrogradation (green wave effect) of natural vegetation. NASA/GSFC, Type III, Final Report, Greenbelt, Maryland, USA, 1974.

15. Tucker, C.J. Red and photographic infrared linear combinations for monitoring vegetation. Remote Sens. Environ. 1979, 8, 127-150, DOI: 10.1016/0034-4257(79)90013-0.

16. Djokic, D., Ye, Z.; Dartiguenave, C. Arc Hydro tools overview. Esri, Redlands, California, USA, 2011.

17. Forman, R.T.T. Land mosaics: the ecology of landscapes and regions. Cambridge University Press: Cambridge, UK, 1995.

18. Roth, N.E.; Allan, J.D.; Erickson, D.L. Landscape influences on stream biotic integrity assessed at multiple spatial scales. Landscape Ecol. 1996, 11, 141-156, DOI: 10.1007/BF02447513.

19. Wenger, S. A review of the scientific literature on riparian buffer width, extent and vegetation. Office of Public Service and Outreach, Institute of Ecology, University of Georgia, Athens, Georgia, USA, 1999.

20. Arnold, J.G.; Kiniry, J.R.; Srinivasan, R.; Williams, J.R.; Haney, E.B.; Neitsch, S.L. Soil and water assessment tool: input/output documentation. Texas A\&M University: Temple, Texas, USA, 2012.

21. Dufrêne, M.; Legendre, P. Species assemblages and indicator species: the need for a flexible asymmetrical approach. Ecol. Mongr. 1997, 67, 345-366, DOI: 10.1890/0012-9615(1997)067[0345:SAAIST]2.0.CO;2.

22. Winemiller, K.O. Life history strategies, population regulation, and implications for fisheries management. Can. J. Fish. Aquat. Sci. 2005, 62, 872-885, DOI: 10.1139/f05-040.

23. Hoeinghaus, D.J.; Winemiller, K.O.; Birnbaum, J.S. Local and regional determinants of stream fish assemblage structure: inferences based on taxonomic vs. functional groups. J. Biogeogr. 2007. 34, 324-338, DOI: 10.1111/j.1365-2699.2006.01587.x.

24. Alford, J.B. Multi-scale assessment of habitats and stressors influencing stream fish assemblages in the Lake Pontchartrain Basin, USA. Hydrobiologia. 2014, 738, 129-146, DOI: 10.1007/s10750-014-1925-2.

25. Winemiller, K.O; Rose, K.A. Patterns of life-history diversification in North American fishes: implications for population regulation. Can. J. Fish. Aquat. Sci. 1992, 49, 2196-2218, DOI: 10.1139/f92-242.

26. Johnson, L.B.; Richards, C.; Host, G.E.; Arthur, J.W. Landscape influences of water chemistry in Midwestern streams. Freshwater Biol. 1997, 37, 193-208, DOI: 10.1046/j.1365-2427.1997.d01-539.x.

27. Gardiner, E.P.; Sutherland, A.B.; Bixby, R.J.; Scott, M.C.,;Meyer, J.L., Helfman; G.S., Benfield; F.E., Pringle; C.M., Bolstad; P.V.; Wear, D.N. Linking stream and landscape trajectories in the southern Appalachians. Environ. Monit. Assess. 2009, 156, 17-36, DOI: 10.1007/s10661-008-0460-x.

28. Helms, B.S.; Schoonover, J.E.; Feminella, J.W. Assessing influences of hydrology, physicochemistry, and habitat on stream fish assemblages across a changing landscape. J Amer Water Assoc 2009, 45, 157-169, DOI: 10.1111/j.1752-1688.2008.00267.x.

29. Quinn, J.M.; Cooper, A.B.; Davies-Colley; R.J., Rutherford; J.C., Williamson, R.B. Land-use effects on habitat, water quality, periphyton, and benthic invertebrates in Waikato, New Zealand, hill-country streams. New Zeal. J. Mar. Fresh. 1997, 31, 579-597, DOI: 10.1080/00288330.1997.9516791.

30. Rowe, D.C.; C.L. Pierce; Wilton, T.F. Physical habitat and fish assemblage relationships with landscape variables at multiple spatial scales in wadeable Iowa streams. N. Am. J. Fish. Manage. 2009, 29: 1333-1351, DOI: 10.1577/M08-193.1.

31. Lu, Y.; Bauer, J.E.; Canuel, E.A.; Yamashita, Y.; Chambers, R.; Jaffe, R. Photochemical and microbial alteration of dissolved organic matter in temperate headwater streams associated with different land use. J. Geophys Res-Biogeo. 2013, 118, 566-580, DOI: 10.1002/jgrg.20048.

32. Keck, B.P.; Marion, Z.H.; Martin, D.J.; Kaufman, J.C.; Harden, C.P.; Schwartz, J.S.; Strange, R.J. Fish functional traits correlated with environmental variables in a temperate biodiversity hotspot. PLoS One 2014, 9, e93237, DOI: 10.1371/journal.pone.0093237.

33. Cochran, P.A.; Lyons, J. The Saffron Shiner (Notropis rubricroceus) as a nest associate of the River Chub (Nocomis micropogon). J. TN. Acad. Sci. 2001, 76, 61-62.

34. Zamor, R.M.; Grossman, G.D. Turbidity affects foraging success of drift-feeding rosyside dace. Trans. Am. Fish. Soc. 2007, 136, 167-176, DOI: 10.1577/T05-316.1.

35. Kemp, P.; Sear. D.; Collins; A., Naden, P.; Jones, I. The impacts of fine sediment on riverine fish. Hydrol. Process. 2011, 25, 1800-1821, DOI: 10.1002/hyp.7940. 
36. Sutherland, A.B.; Meyer, J.L. Effects of suspended sediment on growth rate and gill condition of two Southern Appalachian minnows. Environ. Biol. Fish. 2007, 80, 389-403, DOI: 10.1007/s10641-006-9139-8.

37. Sutherland, A.B., Meyer, J.L.; Gardiner, E.P. Effects of land cover on sediment regime and fish assemblage structure in four Southern Appalachian streams. Freshwater Biol. 2002, 47, 1791-1805, DOI: 10.1046/j.13652427.2002.00927.x.

38. Midway, S.R.; Wagner, T.; Tracy, B.H. A hierarchical community occurrence model for North Carolina stream fish. Trans. Am. Fish. Soc. 2014, 143, 1348-1357, DOI: 10.1080/00028487.2014.931745.

39. Blevins, Z.W; Effert, E.L.; Wahl, D.H.; Suskia, C.D. Land use drives the physiological properties of a stream fish. Ecol. Indic. 2013, 24, 224-235, DOI: 10.1016/j.ecolind.2012.06.016.

40. Van den Brink, P.J.; Alexander, A.C.; Desrosiers, M.; Goedkoop, W.; Goethals, P.L.M.; Matthias, L.; Scott, D.D. Traits-based approaches in bioassessment and ecological risk assessment: strengths, weaknesses, opportunities and threats. Integr. Environ. Assess. Manage. 2011, 7, 198-208, DOI: 10.1002/ieam.109.

41. Kimmel, W.G.; Argent, D.G. Stream fish community responses to a gradient of specific conductance. Water Air Soil Poll. 2010, 206, 49-56, DOI: 10.1007/s11270-009-0085-x.

42. U.S. Environmental Protection Agency (USEPA). A field-based aquatic life benchmark for conductivity in central Appalachian streams. Final Report. EPA/600/R-10/023F. Washington, D.C., 2011.

43. Griffith, M.B. Natural variation and current reference for specific conductivity and major ions in wadeable streams of the conterminous USA. Freshwater Sci. 2014, 33, 1-17.

44. Rashleigh, B. Relation of environmental characteristics to fish assemblages in the upper French Broad River basin. Environ. Mon. Assess. 2004, 93, 139-156, DOI: 10.1023/B:EMAS.0000016806.69647.3e.

45. Hitt, N.P.; Floyd, M.; Compton, M.; McDonald, K. Threshold responses of Blackside Dace (Chrosomus cumberlandensis) and Kentucky Arrow Darter (Etheostoma spilotum) to stream conductivity. Southeast. Nat. 2016, 15, 41-60, DOI: 10.1656/058.015.0104.

(C) 2017 by the authors; licensee Preprints, Basel, Switzerland. This article is an open access article distributed under the terms and conditions of the Creative Commons by Attribution (CC-BY) license (http://creativecommons.org/licenses/by/4.0/). 